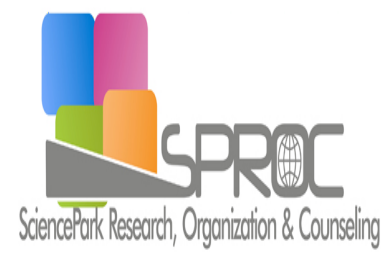

\title{
New Trends and Issues Proceedings on Humanities and Social Sciences
}

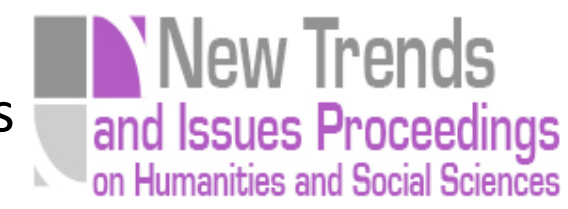

Issue 5 (2016) 130-137

Selected paper of 4th Cyprus International Conference on Educational Research (CYICER-2015) March 19 - 21, 2015, Girne American University in Kyrenia, CYPRUS

\section{Conditions for effective interaction between teacher and pupil}

\author{
Dominika Provazkova Stolinska ${ }^{a}$, Zizkovo nam. 5, Olomouc, 771 40, Czech Republic
}

\section{Suggested Citation:}

Stolinska, D. P. (2016). Conditions for effective interaction between teacher and pupil. New Trends and Issues Proceedings on Humanities and Social Sciences. [Online]. 05, pp 130-137. Available from: www.prosoc.eu

Selection and peer review under responsibility of Assoc. Prof. Dr. Cigdem Hursen, Near East University

${ }^{\circ} 2016$ SciencePark Research, Organization \& Counseling. All rights reserved.

\begin{abstract}
In accordance with the objectives of the grant project no. IGA_PdF_2015_007 called Puberty - Sex education system in the Czech and Chinese education we introduce input on the issue of interaction between teacher and pupil. Here we see as fundamental building block for the adoption of the partnership status of the two main actors of the educational process and intervene as barriers to communication in specific issues such as sex education. By the presentation of paper we would like to highlight the timeliness issue of teacher-pupil interaction at primary school because we have to use the targeted socialization of young people In the process of teacher-pupil interaction we could see the obvious and unquestionable importance of being a teacher. The pupil is indeed perceived as an active part of the educational process, but the purpose of primary school (among other things) is to equip the pupil self-assessment skills. Through the contribution we would like to introduce the quality of problems in the real environment at Czech primary schools. Data was gathered from the implementation of controlled observation in 50 classes at primary schools and will be processed through behavioral technique by J. Pelikan, with answers to research questions will operationalized the above-mentioned research project.
\end{abstract}

Keywords: Czech environment; primary school; sex education; communication

* ADDRESS FOR CORRESPONDENCE: Dominika Provazkova Stolinska, Zizkovo nam. 5, Olomouc, 771 40, Czech Republic E-mail address: dominika.stolinska@gmail.com / Tel.: +4-345-343-21. 
Stolinska, D. P. (2016). Conditions for effective interaction between teacher and pupil. New Trends and Issues Proceedings on Humanities and Social Sciences. [Online]. 05, pp 130-137. Available from: www.prosoc.eu

\section{Introduction}

The issue of communication and interaction between teacher and pupil is currently very topical. Especially increasing importance in the context of issues dealt with the project Puberty - part of sex education in the system of Czech and Chinese Education no. IGA_PdF_2015_007. Sex education is in general often attacked other parts of the parental public as unnecessary and ineffective school. Best sex education in school also follows from the requirement of expertise, and in relation to specific pedagogical-psychological peculiarities of pupils (eg. Langmeier \& Krejcirova, 2006) and it need to respect humanizing criteria and ethical principles. Comprehensive sex education, including issues of puberty, has a center of gravity in the family, but cannot guarantee that the pupil obtains the desired knowledge, attitudes and behavior of the broadest sexual behavior. A school pupil and its family should be able to communicate with each other on sex education, including the issue of puberty, but often there are problems associated with barriers parents in communicating with the child (Raskova, 2013).

These drawbacks can be eliminated by promoting communication between home and school and the development of effective communication between teacher and pupil. As positive for these purposes may impress the fact that studies have shown that the main actor, who manages educational communication in the educational process is the teacher. He specifies the main focus time and communication activities. In the context of the requirements of contemporary curricular reform is possible to evaluate progress in the area of communication between teacher and pupil in the sense that today has a pupil created sufficient space for voicing its own teacher requirements and provides feedback to the teacher's response (Stolinska, 2009). This phenomenon can be seen as a prerequisite for the adoption of partner status in both the primary actors in the educational process and intervene as barriers to communication in specific issues such as sex education.

The results of the educational process, especially in the context of the specificities of communication and interaction, it is possible to build further stimulating the development of relations between school and family (or between the teacher and the pupil's parents).

\section{Cooperation between teachers and parents}

By Prucha (2000) many educators argue that without good relations and cooperation between parents and schools cannot operate successfully youth education. The Czech environment uses this approach not so long. Earlier prevailing notion that the role of parents and the school are two separate activities - role of schools is to educate and the role of the family is to bringing up. Since the 80 s of the 20th century is this approach changed.

But reality is not always easy. Much of factors intervene that. The important requirement is the pursuit of mutual cooperation in achieving the same goal - the development of the child.

When talking about the problems of different expectations of both the environment in which the child develops, it is appropriate to look at the particular point of view.

First, we focus on the answer to the first question - Which schools the parents want?

With the onset of reform ideas has also been a parent public interested in the idea of pluralism in education. A fundamental shift in parental interest in school is seen in response to the transformation of Czech education system. The research results by AISA showed that $34 \%$ of the parental population (designated type generally liberal) reacts to a fundamental transformation of the education system and promotes a positive, although a majority of respondents in this group has to present education tolerant relationship. $16 \%$ of respondents (type radically liberal) expressed quite clearly support a radical transformation of the Czech school system and also showed relatively sharp criticism of the current school for that suppresses individuality and personality of the child. Three quarters of 
Stolinska, D. P. (2016). Conditions for effective interaction between teacher and pupil. New Trends and Issues Proceedings on Humanities and Social Sciences. [Online]. 05, pp 130-137. Available from: www.prosoc.eu

respondents in this group also expressed the need to have a greater impact on teaching their children at school. The second half of the respondents expressed against decentralization of education and supported the original - the traditional school system. (Mecnerova In Pedagogy III., 1996).

The OECD is focused on the parents' expectations in the research - what the most important areas should be developed in children at schools. In conclusion there defined 8 parts. The following table presents the results obtained:

Table 1: What qualities and skills has to be developed at the schools (view of parents)

\begin{tabular}{ccc}
\hline QUALITIES AND SKILLS & $\begin{array}{c}\text { Proportion of respondents who consider essential element for (\%) } \\
\text { diameter of OECD countries }\end{array}$ & CZE \\
\hline $\begin{array}{c}\text { pupils' confidence } \\
\text { the ability to live with people } \\
\text { from different layers } \\
\begin{array}{c}\text { understanding of life in other } \\
\text { countries }\end{array}\end{array}$ & 88 & 56 \\
$\begin{array}{c}\text { Healthy Lifestyle } \\
\text { the ability to be a good citizen }\end{array}$ & 64 & 37 \\
important capabilities for further \\
study
\end{tabular}

Source: (Prucha, 1997)

The second question, which we focus here, is: Which parents the schools want?

First, we must remember, that the primary educational system has been transformed on many

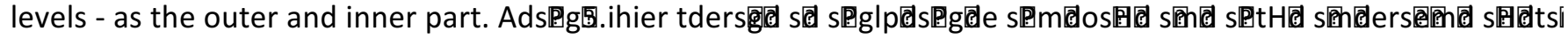


intentional infliction of human development. The current trend in line with the philosophy of contemporary school reform is the implementation of an interactive learning process.

\section{Interactive teaching and learning processes}

Modern education in the Czech Republic stands on the foundations of pedagogical constructivism. This current puts the greatest emphasis on exploration, expansion and deformation structures in the learning process. Pedagogical constructivism is not intended to pass only truth. The trend of today's educational goals is to equip pupils with the ability to navigate in a large amount of knowledge and learn how to properly use them. At school he realizes pedagogical constructivism in the form of opportunities for sharing of opinions, ideas and original understanding of the problem.

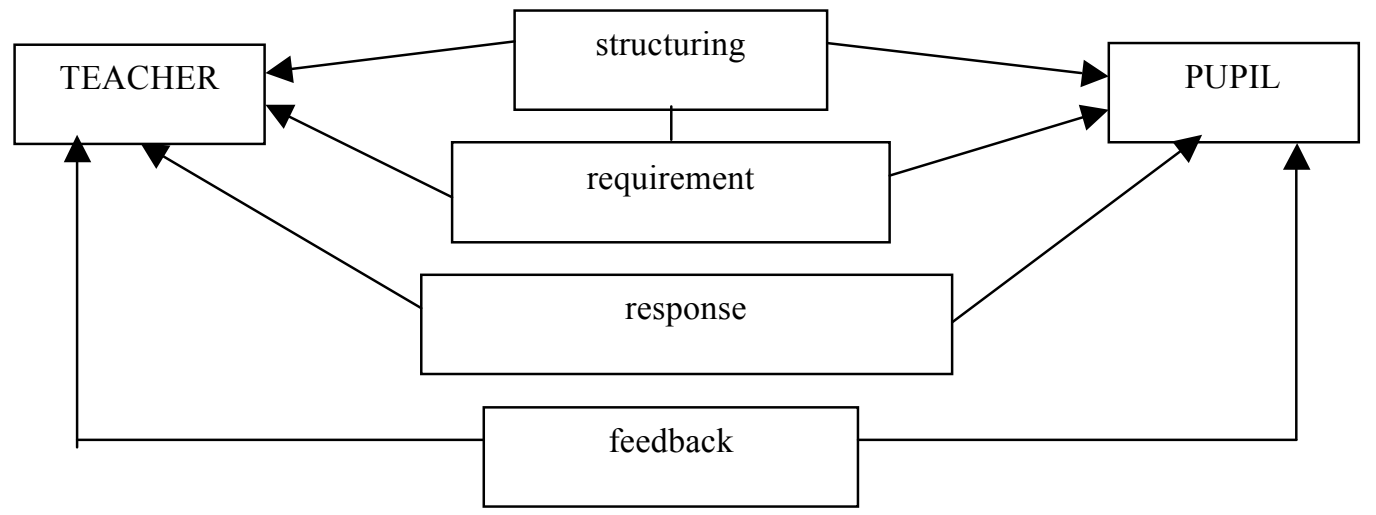

Figure 1: Interactive structure in interactive teaching

As can be seen from the figure, the pupil is becoming initiated learning activities. Pupil submits proposals, helps to create and participates in the management of the educational process. But it is necessary to respect the teacher's rules. The question is how far the usual practice is from the vision of reform.

\section{Research on teacher-pupil interaction}

\subsection{Design of Research}

Realized transdisciplinary research has the character of quantitative with qualitative elements. Overall the survey attended 50 classes at primary schools (= 50 teachers and 944 pupils). We used the behavioral technique - the typological-interaction research technique that has been in the $80 \mathrm{~s}$ of the 20th century designed by Pelikan. 
Stolinska, D. P. (2016). Conditions for effective interaction between teacher and pupil. New Trends and Issues Proceedings on Humanities and Social Sciences. [Online]. 05, pp 130-137. Available from: www.prosoc.eu

\subsection{Analysis and interpretation of the results of the research}

Histogram z Ipp C 
Stolinska, D. P. (2016). Conditions for effective interaction between teacher and pupil. New Trends and Issues Proceedings on Humanities and Social Sciences. [Online]. 05, pp 130-137. Available from: www.prosoc.eu

Figure 3: Index of interaction

Index of interaction reflects the efficiency of interaction - acceptance or non-acceptance of the possible effect of the teacher's style of action. The defined interval is again determined in the range from -1 to +1 . Actually measured values range from -0.067000 to 0.8880000 .464042 to the median value.

Measured index values interactions range from the diameter to the upper border of the interval, which indicates acceptance of the teacher's operation when use the elements of both styles of action.

! "\#夋 ( ) *+*,-*. 
Stolinska, D. P. (2016). Conditions for effective interaction between teacher and pupil. New Trends and Issues Proceedings on Humanities and Social Sciences. [Online]. 05, pp 130-137. Available from: www.prosoc.eu

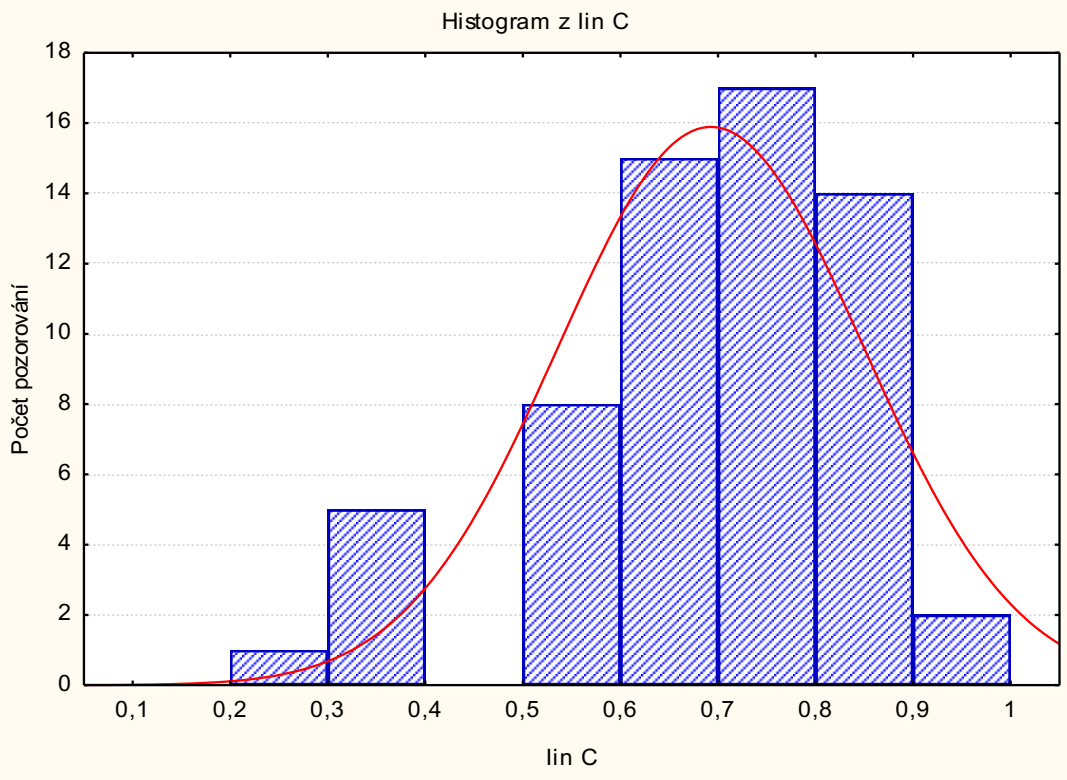

Figure 5: Index integrative interaction

Index integrative interaction reflects the acceptance or rejection of the teacher's action in the use of democratic action. In the same specified interval as given above, the measured values were again from an average of almost through to the upper limit, namely from 0.245000 to 0.910000 from the median value of 0.689525 . We can say that the use of the elements of this action was effective, as evidenced by both the achievement of the upper boundary of the interval and the high number of observations of individual manifestations.

\subsection{Summary and conclusions of the research}

The research revealed the following results:

Question no. 1: What elements of action are most often chosen by teachers?

Can be said that today's teachers do not use clearly neither of the extreme action of styles (authoritative vs. democratic). The most frequent values indicate the ambivalence - i.e. the use of the elements of both styles of action. Strategy choice of the individual elements is quite legible. The choice depends on the type of delivery and the lesson. In the suburbs of lesson and teaching major subjects accumulate greater frequency of use, features authoritative action. Teachers and guide the class to the attention of encouraging or inciting regulate and discipline. Whereas during the hours in the classroom and training of teachers chose rather elements of democratic action.

Question no. 2: What effects of the teachers different strategies have chosen on the interaction between teacher and pupil?

The research results showed that teachers select elements of different styles of action voted efficiently, because the teacher's action was very well received by pupils. Based on data evaluation is possible to evaluate the effect of targeted pupils were fully respected, whether it was used elements of one or the other style action. Elements authoritative influence teachers effectively voted especially in situations needs the attention, securing or maintaining discipline. In case of the use efficiency of democratic interaction effect was even more pronounced. The measured values are in very high numbers reached the upper limit of the interval, which is indicative of success. 
Stolinska, D. P. (2016). Conditions for effective interaction between teacher and pupil. New Trends and Issues Proceedings on Humanities and Social Sciences. [Online]. 05, pp 130-137. Available from: www.prosoc.eu

\section{Conclusions}

The results of the research showed that in a real environment Czech primary school, interaction between teacher and pupil comes to the level of a relationship. This input is very inspiring and favorable area for addressing the issue of how to implement sex education in schools. It is evident that the basis between teachers and pupils to communicate in such a specific topic is created.

As reported Raskova if we see sex education as a space for instilling moral principles and shaping human behavior and attitudes to sexual issues, we can imagine that it is necessary to work on the development of human emotions pupil. Far from not only includes communicating facts, but also the attitudes towards sexual morality and supports the personal autonomy (In Sterbova, Raskova et al., 2014). For our effective efforts we cannot avoid the close collaboration of both environments that surrounds the child - primary and secondary. The themes of our next interest are forms of communication between parents and schools focus on specific educational content.

\section{References}

Brunner, E. J. (2001). Lehrer-Schüler-Interaktion. Handworterbuch Padagogische Psychologie. Weinheim.

Jarvis, P., Holford, J. \& Griffin, C. (2003). The Theory and Practice of Learning. Sterling.

Kolektiv autoru. (1996). Pedagogika III. Ostrava: OSU.

Langmeier, J., \& Krejcirova, D. (2006). Vyvojova psychologie. Praha: Grada.

Prucha, J. (1997). Moderni pedagogika. Praha: Portal.

Prucha, J. (2000). Prehled pedagogiky. Praha: Portal.

Raskova, M. (2013). Sexualni vychova jako zdroj skolni pece o zdravi a zdravy zivotni styl deti. Olomouc: PdF UP.

Sterbova, D. \& Raskova, M. (2014). Specifika komunikace ve vztahu k sexualite I. Olomouc: UP.

Stolinska, D. (2009). Efektivita interakce ucitel-zak na dnesnich skolach. Media4U Magazine. 